\title{
Meaning of Quality Inspection and Control Methods during Manufacturing Process of Metal Sheet Stampings
}

Stanisław Borkowski, Krzysztof Knop, Paweł Szklarzyk

Institute of Production Engineering, Czestochowa University of Technology, Armii Krajowej 19B, 42-200 Czestochowa, Poland. E-mail: bork@zim.pcz.pl; kknop@poczta.fm; szklarzyk.pawel@o2.pl

The paper presents the characteristics of a metal product called 'Back Cover' and its manufacturing process. The characteristic of quality inspection methods and control devices during manufacturing process of analysed product was conducted. An analysis of production and quality problems during manufacturing of the analysed product using qualitative and quantitative tools such as Ishikawa diagram and Pareto-Lorenz diagram were presented. Ishikawa diagram was used to identify areas that generate quality problems and Pareto-Lorenz diagram was used to quantify the quality problems and to distinguish the critical nonconformities. It was presented differences between visual control and visual inspection. BOST research was used to determine the validity of the use of visual control in the analysed company against the remaining factors of the manufacturing process. Created a series of validity of manufacturing process to capture the relationship between the place of the individual factors of the manufacturing process. The use of visual control turned out not to be the most important factor in the manufacturing process, according to the examined company the most important is the use of only reliable technology.

Keyword: manufacturing process, ‘Back Cover’ part, quality inspection methods, visual control, BOST method

\section{References}

[1] BORKOWSKI, S. (2012). Tradycyjne narzędzia zarzadzania jakością. Częstochowa: Oficyna Wydawnicza Srtowarzyszenia Menedżerów jakości i Produkcji. pp. 35-39; 52-55. ISBN 83-89275-26-0.

[2] BORKOWSKI, S., STASIAK-BETLEJEWSKA, R., NÁPRSTKOVÁ, N. (2011). The Kaizen philosophy in the aluminium products improvement. Manufacturing Technology. Vol. 11, No 11, December. pp. 2-5. ISSN 12132489.

[3] BORKOWSKI, S. (2012). Toyotaryzm. Wyniki badań BOST. Warszawa: Wydawnictwo Menedżerskie PTM. pp. 74-75. ISBN 978-83-61949-48-0.

[4] BORKOWSKI, S. (2012). Toyotaryzm. Zasady zarzadzania Toyoty w pytaniach. Warszawa: Wydawnictwo Menedżerskie PTM. pp. 61-70. ISBN 978-83-61949-44-2.

[5] BORKOWSKI, S. (2009). Visual Control as the Basis for the Seventh Rule of Toyota Management. Chapter 1. In: Toyotarity. Visual Control. Ed.: Borkowski S., Tsoy E. B., Makovetsky, Dnipropetrovsk. pp. 10-19. ISBN 978-966-1507-09-7.

[6] BORKOWSKI, S., KNOP, K. (2012). Measurement and Analysis of Visual Control Importance in a Company of Automotive Branch, In: CO-MAT-TECH 2012, Global Crises - Opportunities and Threats. $20^{\text {th }}$ International Scientific Conference. October 10-12, 2012, Trnava, Slovak Republic. Trnava: Vydavatel'stvo Alumnipress. pp. 64-75. ISBN 978-80-8096-180-0.

[7] CZYŻEWSKI, B. (2007). Wewnętrzna kontrola jakości w przedsiębiorstwie produkcyjnym. Poznań: Wielkopolski Kulb Jakości FSNT NOT Poznań, pp. 86-96.

[8] HAMROL, A. (2008). Zarzadzanie jakościa z przykładami. Warszawa: PWN. pp. 268-275; 288-289; 305. ISBN 978-83-01-15374-8.

[9] KONSTANCIAK, M. (2012). Analysis of technological strategies on the example of the production of the tramway wheels. Archives of Materials Science and Engineering. Vol. 57, Iss. 2. pp. 69-74. ISSN 1897-2764.

[10] LASZKIEWICZ, M. (2005). Utrzymanie ruchu to strategiczne aktywa firmy. Inżynieria \& Utrzymanie Ruchu Zakładów Przemystowych. Warszawa: Trade Media Internationial, Marzec 2005. http://www.utrzymanieruchu.pl/menu-gorne/artykul/article/utrzymanie-ruchu-to-strategiczne-aktywa-firmy/

[11] LIKER, J. K. (2005). Droga Toyoty. 14 zasad zarządzania wiodącej firmy produkcyjnej świata. Warszawa: MT Biznes. pp. 240. ISBN 83-88970-31-3.

[12] PRUSSAK, W. (2006). Zarzadzanie jakościa. Wybrane elementy. Poznań: Wydawnictwo Politechniki Poznańskiej. pp. 90-92. ISBN 83-7143-541-X.

[13] ULEWICZ, R.; DIMA, I.C.; GRABARA, J. (2013). Quality Assurance in the Process of Material Selection and Production of Semitrailer Structure Parts. Metalurgia International, Vol. 18, No 7. pp. 195-199. ISSN 15822214.

[14] ULEWICZ, R., NOVY, F. (2013). Instruments of Quality Assurance to Structural Materials. Annals of Faculty Engineering Hunedoara - International Journal of Engineering, 2013, T. 11, No 1. pp. 23-28. ISSN: 1584-2665.

[15] http://www.iqs.pl/en/services/control-by-means-of-measurement-and-control-tools.html 